\title{
A new spider crab (Brachyura, Epialtidae) from the Castle Hayne Limestone Formation (Eocene), North Carolina, USA
}

Un nuevo cangrejo araña (Brachyura, Epialtidae) de la Formación Caliza Castle Hayne (Eoceno), Carolina del Norte, EUA

Alessandro Garassino ${ }^{1, *}$, Giovanni Pasini ${ }^{2}$, Don Clements ${ }^{1}$

${ }^{1}$ North Carolina Museum of Natural Sciences, 11 West Jones Street, Raleigh, North Carolina 27601, USA.

${ }^{2}$ Via Alessandro Volta 16, 22070 Appiano Gentile (Como), Italy.

* Corresponding author: (A. Garassino)

alegarassino@gmail.com

\begin{abstract}
A new spider crab, Eoinachoides bretoni n. sp. (Epialtidae MacLeay, 1838) from the Comfort Member of the Castle Hayne Formation (Eocene) of Onslow County, North Carolina (USA), is herein described, representing the second spider crab recovered from this member. Although the new species does not enlarge the stratigraphical range for the genus which is currently restricted from the Eocene to Miocene, it is the first report in North America, extending the palaeogeographic distribution of Eoinachoides, limited currently in the fossil record of South America. In addition, an updated list of the species of the Castle Hayne Formation is herein provided.
\end{abstract}

Keywords: Crustacea, Decapoda, Majoidea, Paleogene, Castle Hayne Formation, taxonomy.

\section{RESUMEN}

Se describe un nuevo cangrejo araña, Eoinachoides bretoni n. sp. (Epialtidae MacLeay, 1838) del Miembro Comfort de la Formación Castle Hayne (Eoceno) en el Condado de Onslow, Carolina del Norte (EUA), representa el segundo cangrejo araña encontrado en este miembro. Aunque la nueva especie no extiende el alcance estratigráfico del género, restringido actualmente al Eoceno-Mioceno, es el primer reporte para Norteamérica, extendiendo la distribución paleobiogeográfica de Eoinachoides, limitada actualmente al registro fósil de Sudamérica. Se proporciona una lista actualizada de las especies de crustáceos de la Formación Castle Hayne.

Palabras clave: Crustacea, Decapoda, Majoidea, Paleogeno, Formación Castle Hayne, taxonomía.
How to cite this article:
Garassino, A., Pasini, G., Clements, D., 2021, A new spider crab (Brachyura, Epialtidae) from the Castle Hayne Limestone Formation (Eocene), North Carolina, USA: Boletín de la Sociedad Geológica Mexicana, 73 (3), A261220. http://dx.doi.org/10.18268/ BSGM2021v73n3a261220
Manuscript received: November 5, 2020

Corrected manuscript received: December 1, 2020

Manuscript accepted: December 14, 2020

Peer Reviewing under the responsibility of Universidad Nacional Autónoma de México.

This is an open access article under the CC BY-NC-SA license(https://creativecommons.org/licenses/by-nc-sa/4.0/) 


\section{Introduction}

The middle Eocene Castle Hayne Formation (North Carolina) has produced a rich decapod fauna including 13 families (excluding incertae sedis), 19 genera, and 23 species. Though Rathbun (1935) reported two decapods from this formation, there has been little interest in fossil crabs until recently. Bishop and Whitmore (1986) figured several fossils from the Castle Hayne Formation, providing preliminary assignments without descriptions. Later, Salva et al. (1995) introduced the rich decapod fauna and its palaeogeographic implications and Blow and Manning (1996) reported three new genera and eight new species from this formation. Feldmann et al. (1998) gave a new impulse to the knowledge of the decapod fauna of the Castle Hayne Formation, describing four new species and reporting one species previously recorded from the Santee Limestone of South Carolina by Blow and Manning (1996). The most recent contributions to the decapod fauna of the Castle Hayne Formation have been provided by Ossó and Clements (2016) and Davis et al. (2020) who described a new genus and a new species respectively, the latter representing the first report of a decapod crab from the Spring Garden Member of the Castle Hayne Formation (see Table 1).

The purpose of this paper is the description of a new spider crab, Eoinachoides bretoni n. sp. from the Comfort Member of the Castle Hayne Formation from which all decapod crabs known to date have been collected, except Matutites collinsi Davis, Garassino and Weaver, 2020, recovered from the Spring Garden Member of the same formation. It represents the second spider crab reported from the Comfort Member.

\section{Geological setting}

Eoinachoides bretoni n. sp. was collected from the Comfort Member of Ward et al. (1978) from Bartonian aged rocks of the Castle Hayne Formation in the north quarry at approximately $34^{\circ}$ $50^{\prime} 34.4^{\prime \prime} \mathrm{N}$ x $77^{\circ} 32^{\prime} 45.3$ 'W (Figure 1). Harris and Zullo (1991) reported five sequences within the Castle Hayne ranging in age from Lutetian to Priabonian. Temporal placement of Eoinachoides bretoni $\mathrm{n}$. sp is possible based upon Kier's echinoid biozones (Kier, 1980). Indeed, E. bretoni n. sp was found associated with Middle Biozone echinoids such as Linthia harmatucki Kier, 1980 and Eurodia rugosa depressa Kier, 1980. Kier's Middle Biozone correlates to sequence 2 and 3 of Harris and Zullo (1991) which is Bartonian. An excellent graphic correlating the lithosomes of Ward et al. (1978), the sequence stratigraphy of Harris and Zullo (1991) and Kier's echinoid biozones can be found in Ciampaglio et al. (2007).

Simms (2012: 42) reported nearly $100 \mathrm{ft}$. (ca. $30 \mathrm{~m}$.) of Castle Hayne Formation at the Onslow Quarry. The overburden varies from 2 to $57 \mathrm{ft}$. (from $c a .0 .6 \mathrm{~m} . c a .17 \mathrm{~m}$.) with much of the variable thickness a factor of the Castle Hayne formation's dissolution and sediment filled stream erosion features, as the modern landscape has almost no relief. The section where E. bretoni n. sp was discovered is in the upper product limestone at the new north quarry. In other areas with less overburden in nearby quarries, there have been younger Castle Hayne formation rocks that include Kier's late echinoid biozone above a sequence break that is Priabonian. The provenance of E. bretoni n. sp. does not include rocks of this age.

\section{Systematic paleontology}

Superfamily Majoidea Samouelle, 1819

Family Epialtidae MacLeay, 1838

Subfamily Epialtinae MacLeay, 1838

Genus Eoinachoides Van Straelen, 1933

Type species: Eoinachoides senni Van Straelen, 1933, by original designation [late Eocene (Priabonian) - Venezuela (South America)].

Other fossil species: Eoinachoides latispinosa Carriol, de Muizon and Secrétan, 1987, Miocene - Argentina, Peru, Venezuela (South America); E. bretoni n. sp., middle Eocene (Bartonian) - North Carolina (USA) (herein). 
Table 1. Updated list of decapod crustaceans from the Castle Hayne Formation (after Blow and Manning, 1996; Feldmann et al., 1998; Clements, 2014; Ossó and Clements, 2016; Davis et al., 2020).

Family Diogenidae Ortmann, 1892

Genus Paguristes Dana, 1851

Paguristes wheeleri Blow and Manning, 1996

Family Dromiidae De Haan, 1833

Genus Dromidia Stimpson, 1858

Dromidia bedetteae Blow and Manning, 1996

Family Homolidae De Haan, 1839

Genus Prohomola Karasawa, 1992

Prohomola katunai? Blow and Manning, 1996

Family Raninidae De Haan, 1839

Genus Cyrthorina Monod, 1956

Cyrthorina fusseli Blow and Manning, 1996

Genus Lophoranina Fabiani, 1910

Lophoranina raynorae Blow and Manning, 1996

Family Calappidae De Haan, 1833

Genus Calappilia A. Milne-Edwards in De Bouillé, 1873

Calappilia sitzi Blow and Manning, 1996

Family Matutidae De Haan, 1841

Genus Matutites Blow and Manning, 1996

Matutites collinsi Davis, Garassino and Weaver, 2020

M. miltonorum Feldmann, Bice, Schweitzer Hopkins, Salva and Pickford, 1998

Family Majidae Samouelle, 1819

Genus Wilsonimaia Blow and Manning, 1996

Wilsonimaia ethelae Blow and Manning, 1996

W. scheiderorum Blow and Manning, 1996

Family Parthenopidae MacLeay, 1838

Genus Acantholambrus Blow and Manning, 1996

Acantholambrus baumi Blow and Manning, 1996

Family Cancridae Latreille, 1802

Genus Sarahcarcinus Blow and Manning, 1996

Sarahcarcinus campbellorum Blow and Manning, 1996 (=Pororaria? granulosa Feldmann, Bice, Schweitzer Hopkins, Salva and Pickford, 1998

Genus Santeecarcinus Blow and Manning, 1996

Santeecarcinus harmatuki Blow and Manning, 1996

Family Carpilidae Ortmann, 1893

Genus Eocarpilius Blow and Manning, 1996

Eocarpilius blowi Feldmann, Bice, Schweitzer Hopkins, Salva and Pickford, 1998

E. carolinensis Blow and Manning, 1996

Family Tumidocarcinidae Schweitzer, 2005

Genus Lobonotus A. Milne-Edwards, 1863

Lobonotus sturgeoni (Feldmann, Bice, Schweitzer Hopkins, Salva and Pickford, 1998)

Family Zanthopsidae Vía Boada, 1959

Genus Martinetta Blow and Manning, 1997

Martinetta palmeri Blow and Manning, 1997

Genus Neozanthopsis Schweitzer, 2003

Neozanthopsis carolinensis (Rathbun, 1935)

Pilumnoidea Samouelle, 1819

Family incertae sedis

Genus Pilummede Ossó and Clements, 2016

Pilummede penderensis Ossó and Clements, 2016

Family Pilumnidae Samouelle, 1819

Genus Viacarcinus Blow and Manning, 1996

Viacarcinus druidi Blow and Manning, 1996

Xanthoidea incertae sedis

Genus Titanocarcinus A. Milne-Edwards, 1863

Titanocarcinus euglyphos Bittner, 1875

Family Oziidae Dana, 185

Genus Menippe De Haan, 1833

Menippe anomala Rathbun, 1935

M. burnsi Rathbun, 1935 


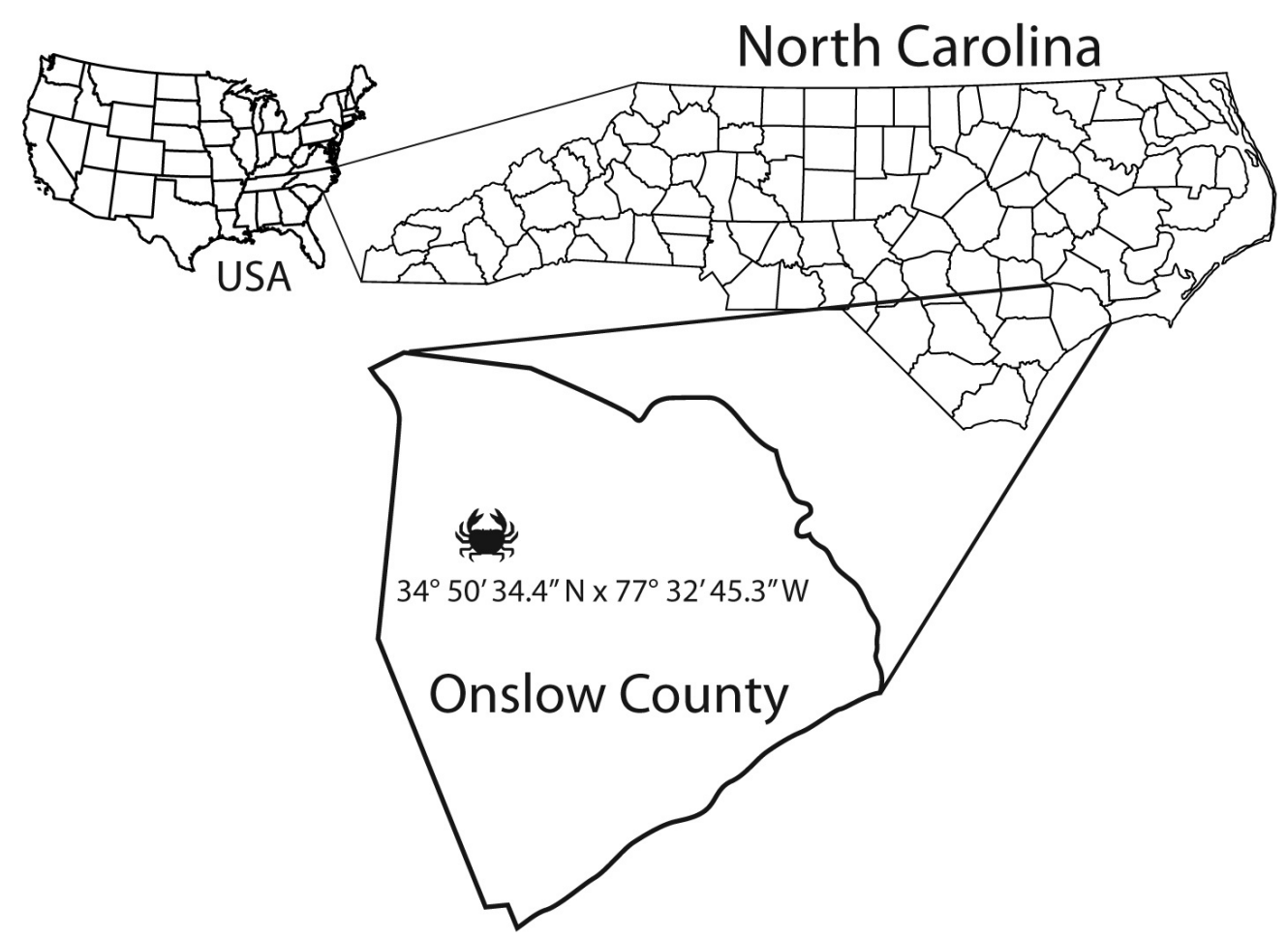

Figure 1 Map of the Onslow County (North Carolina, USA), reporting the coordinates of the fossiliferous locality.

Eoinachoides bretoni n. sp.

Figures 2A to 2D

Diagnosis: Pyriform carapace, slightly longer than wide; front slightly protruded forward, axially depressed, with a pair of lateral tuberculate ridges; protogastric region with one median tubercle; triangular-shaped mesogastric region with one distal tubercle; subpentagonal-shaped cardiac region with a pair of median tubercles; smooth depressed intestinal region; smooth orbital and hepatic regions; inflated subhepatic region with a transverse ridge of three aligned small tubercles; epibranchial region with one lateral tubercle; mesobranchial region with a median tubercle; gastric regions slightly tuberculate; hepatic, cardiac, and branchial regions covered with small tubercles uniformly arranged.

Etymology: after Gérard Breton (1944-2019) for his important contribution to the knowledge of the Cenozoic fossil crabs.

Type material: Holotype, NCSM 12629 (carapace length: $26 \mathrm{~mm}$; maximum carapace width at level of mesobranchial region: $23 \mathrm{~mm}$ ). (NCSM $=$ NG Museum of Natural Sciences, Raleigh, North Carolina, USA).

Type locality: Onslow quarry (= Richlands quarry), Onslow County, NC.

Stratigraphy: Eocene (Bartonian), Comfort Member of the Castle Hayne Formation.

Description: Pyriform carapace, slightly longer than wide, widest at level of mesobranchial regions; carapace regions with swellings; apparently short bifid rostrum slightly protruded forward, axially depressed; very narrow orbits; supraorbital eave poorly preserved, apparently without intercalated spine; slightly spiny anterolateral margin almost straight; slightly spiny posterolateral margin strongly convex; smooth, short posterior margin weakly convex medially; smooth epigastric region; protogastric region with one median large tubercle and a pair of small median tubercles, aligned to form a square-shaped structure; triangular-shaped mesogastric region with one distal tubercle; smooth metagastric region with two deep gastric pits; smooth depressed urogastric 
region; pentagonal-shaped cardiac region with a pair of median tubercles; smooth depressed intestinal region; smooth orbital and hepatic regions; inflated subhepatic region with a transverse ridge of three aligned small tubercles; branchial regions strongly inflated; epibranchial region with one lateral tubercle; mesobranchial region with a median tubercle; smooth metabranchial region; deep, sinuous cervical groove; gastric regions slightly tuberculate; hepatic, cardiac, and branchial regions covered with small tubercles uniformly arranged. Cephalic and thoracic appendages and ventral parts not preserved.

Discussion: Although the supraorbital eave is poorly preserved, based upon Schweitzer et al. (2020), the studied specimen has been tentatively assigned to Eoinachoides Van Straelen, 1933 in having carapace ovate, narrowed anteriorly and widened posteriorly, axial regions well defined, and cardiac region with a pair of tubercles. Based

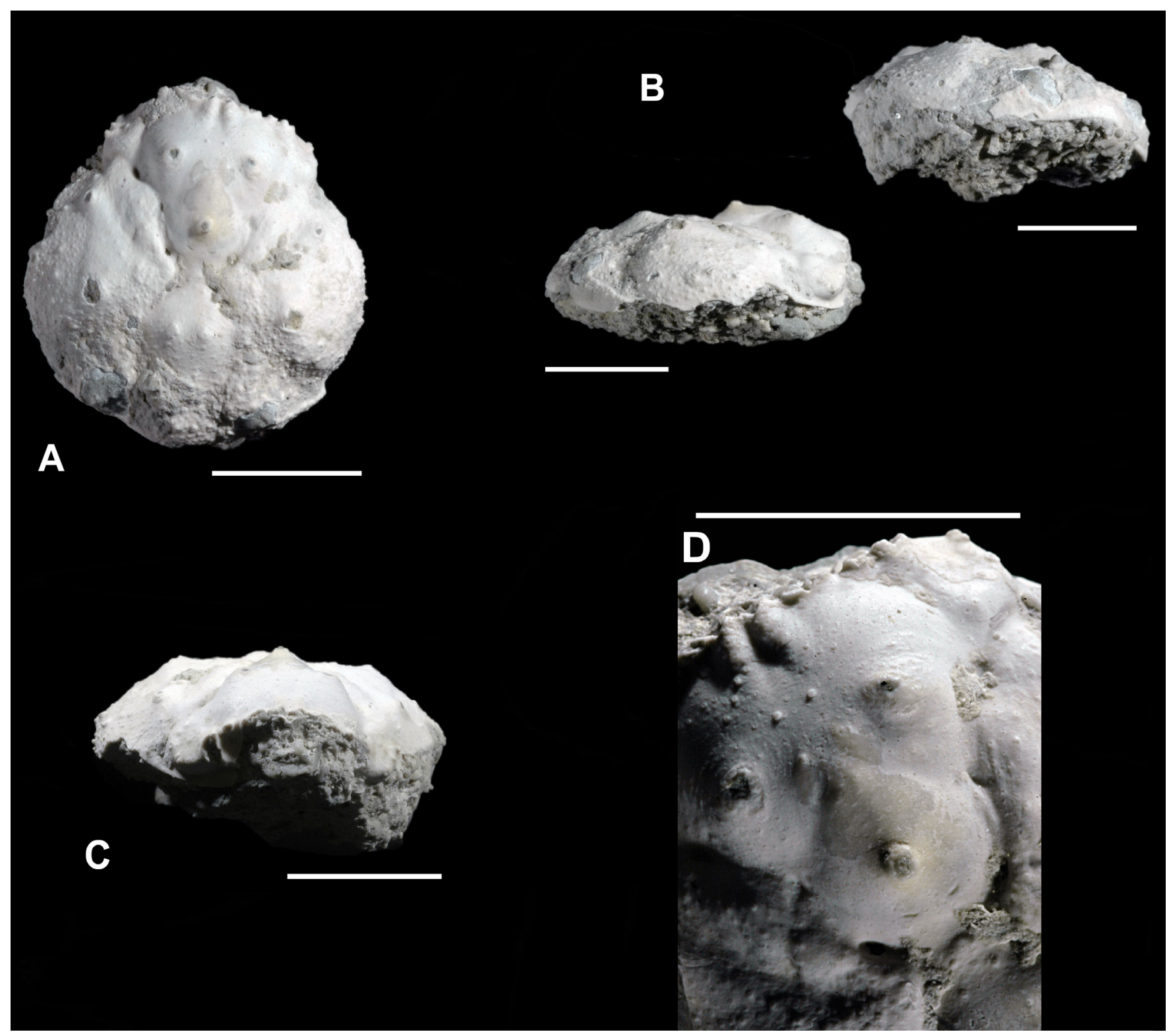

Figure 2 Eoinachoides bretoni n. sp., NCSM 12629. A) Dorsal view. B) Lateral views. C) Frontal view. D) Close-up of the frontal and gastric regions. Scale bar equals $1 \mathrm{~cm}$. Photographs: R. Chandler. 
upon Schweitzer et al. (2010) this genus includes just two species, E. senni Van Straelen, 1933 from the Eocene of Venezuela and E. latispinosa Carriol, de Muzon and Secrétan, 1987, from the Miocene of Argentina, Peru, and Venezuela (Feldmann and Schweitzer, 2004; Collins et al., 2009; Aguilera et al., 2010; Luque et al., 2017).

Eoinachoides senni was described by Van Straelen (1933: 6, 7) from one complete carapace. The smooth protogastric regions distinguish this species from $E$. bretoni n. sp. having protogastric regions with one median tubercle.

Eoinachoides latispinosa was described by Carriol, de Muizon and Secrétan (1987: 8, 9) from one incomplete carapace. The smooth protogastric regions, the mesogastric region with three aligned tubercles, and the mesobranchial regions with a semi-circle row of four tubercles distinguish this species from E. bretoni n. sp. having protogastric regions with one median tubercle, mesobranchial region with one distal tubercle, and mesobranchial region with one median tubercle.

In conclusion, although the new species does not enlarge the stratigraphical range for the genus which is currently restricted from the Eocene to the Miocene, it represents the first report in North America, extending the palaeogeographic distribution of Eoinachoides, limited currently in the fossil record of South America.

\section{Acknowledgements}

We thank L. McCall, North Carolina, for donating the studied specimen to the North Carolina Museum of Natural Sciences (Raleigh); R. Chandler, North Carolina, for the photographs of the specimen; H. Karasawa, Mizunami Fossil Museum, Japan, for useful suggestions about the systematic assignment of the studied specimen; $\mathrm{T}$. Nyborg, Loma Linda University, California, and O. González León, Facultad de Estudios Superiores Iztacala, Mexico, for careful review and criticism. Plant Manager Doug Fetsco and Danny Humphries generously allowed access to the
Martin Marietta Onslow quarry for our research. Without Martin Marietta quarry access across the Carolinas, very little would have been published on Castle Hayne and Santee Formation decapod crustaceans.

\section{References}

Aguilera, O., Rodrigues de Aguilera, D., Vega, F.J., Sánchez-Villagra, M., 2010, Mesozoic and Cenozoic decapod crustaceans from Venezuela and related trace-fossil assemblages, in Sánchez-Villagra, M., Aguilera, O., Carlini, A.A. (eds.), Urumaco and Venezuelan paleontology: Bloomington, Indiana University Press. 103-128 pp.

Bishop, G.A., Whitmore,J.L., 1986, The Paleogene crabs of North America: Occurrence, preservation, and distribution: SEPM Guidebook, Southeastern United States, Third Annual Midyear Meeting, 297-306.

Bittner, A., 1875, Die Brachyuren desvicentinischen Tertiärgebirges: Denkschriften der Kaiserlichen Akademie der Wissenschaften in Wien, 34, 63-106.

Blow, W.C., Manning, R.B., 1996, Preliminary descriptions of 25 new decapod crustaceans from the Middle Eocene of the Carolinas, U.S.A.: Tulane Studies in Geology and Paleontology, 29(1), 1-26.

Blow, W.C., Manning, R.B., 1997, A new genus, Martinetta, and two new species of xanthoid crabs from the Middle Eocene Santee Limestone of South Carolina: Tulane Studies in Geology and Paleontology, 30(3), 171-190.

Ciampaglio, G., Donovan, S.K., Weaver, P.G., 2007, A new bourgueticrinid (Crinoidea) from the Castle Hayne Formation (Eocene) of southeastern North Carolina, USA: Swiss Journal of Geosciences, 100(2), 243-249. https://doi.org/10.1007/s00015-007-1221-5

Carriol, R.P., de Muizon, C., Secrétan, S., 1987, Les crustacés (Cirripedia et Decapoda) du Néogène de la Côte Péruvienne: Annales de 
Paléontologie (Vert.-Invert.), 73(3), 137-164.

Clements, D.N., 2014, Cretaceous and Paleogene Decapods, in Richard Chandler (ed.) Fossil Invertebrates - Plants Volume I: North Carolina Fossil Club, USA, 300 p.

Collins, J.S.H., Portell, R.W., Donovan, S.K., 2009, Decapod crustaceans from the Neogene of the Caribbean: diversity, distribution and prospectus: Scripta Geologica, 138, 55-111.

Dana, J.D., 1851, Conspectus crustaceorum quae in orbis terrarum circumnavi gatione, Carolo Wilkes e classe reipublicae foederatae duce, lexit et descripsit: Paguridea: Proceedings of the Academy of Natural Sciences of Philadelphia, 5(10), 267-272. https://doi. org/10.5962/bhl.title.53615

Davis, D.J., Garassino, A., Weaver, P.G., 2020, Matutites collinsi n. sp. (Crustacea, Decapoda, Matutidae) from the Spring Garden Member of the Castle Hayne Formation in North Carolina (USA): Neues Jahrbuch für Geologie und Paläontologie, Abhandlungen, 296(1-2), 67-71. https://doi.org/10.1127/ njgpa/2020/0870

De Bouillé, R., 1873, Paléontologie de Biarritz et de quelques autres localités des BassesPyrénées: Compte-Rendu Travaux Congrès Scientifique de France $\left(39^{\mathrm{e}}\right.$ session à $\left.\mathrm{Pau}\right)$, 427-450.

De Haan, W., 1833-1849, Crustacea, in Siebold, P.F. v. (ed.), Fauna Japonica, sive descriptio animalium, quae in itinere per Japoniam, jussu et auspiciis superiorum, qui summum in India Batava imperium tenent, suscepto, annis 1823-1830 collegit, notis, observationibus a ad- umbrationibus illustravit. 243; Lugduni Batavorum (Arnz). https://doi.org/10.5962/bhl.title.124951

Fabiani, R., 1910, I Crostacei terziari del Vicentino. Illustrazione di alcune specie e Catalogo generale delle forme finora segnalate nella Provincia: Bollettino del Museo Civico di Vicenza, 1(1), 29-45.

Feldmann, R.M., Bice, K.L., Schweitzer Hopkins, C.E., Salva, E.W., Pickford,
K., 1998, Decapod crustaceans from the Eocene Castle Hayne Limestone, North Carolina: paleoceanographic implications: The Paleontological Society Memoirs, 48, 1-28. https://doi.org/10.1017/ s0022336000059916

Feldmann, R.M., Schweitzer, C.E., 2004, Decapod crustaceans from the Lower Miocene of north-western Venezuela (Cerro La Cruz, Castillo Formation): Palaeontology, 71, 7-22. Harris, W.B., Zullo, V.A., 1991, Eocene and Oligocene stratigraphy of the outer Coastal Plain of North and South Carolina, in Horton, J.W., Zullo, V.A. (eds.), The geology of the Carolinas: Knoxville, Carolina Geological Society, $50^{\text {th }}$ Anniversary Volume, and the University of Tennessee Press, 251-262.

Karasawa, H., 1992, Fossil decapod crustaceans from the Manda Group (Middle Eocene), Kyushu,Japan: Transactions and Proceedings of the Palaeontological Society of Japan, 167, 1247-1258.

Kier, P.M., 1980, Echinoids of the Middle Eocene Warley Hill Formation, Santee Limestone, and Castle Hayne Limestone of North and South Carolina: Smithsonian Contributions to Paleobiology, 39, 102 p. https://doi. org/10.5479/si.00810266.39.1

Latreille, P.A., 1802, Histoire naturelle générale et particulière, des Crustacés et des Insectes. Ouvrage faisant suite aux Euvres de Leclerc de Buffon, et partie du Cours complet d'Histoire naturelle rédigé par C.S. Sonnini, membre de plusieurs Sociétés savantes. Paris, Dufart. 5, 407 p. https://doi.org/10.5962/ bhl.title. 15764

Luque, J., Schweitzer, C.E., Santana, W., Portell, R.W., Vega, F.J., Klompmaker, A.A., 2017, Checklist of fossil decapod crustaceans from tropical America. Part I: Anomura and Brachyura: Nauplius, 25, e2017025. https:// doi.org/10.1590/2358-2936e2017025

MacLeay, W.S., 1838, On the Brachyurous Decapod Crustacea. Brought from the Cape by Dr. Smith. Illustrations of the Zoology of South Africa; consisting chiefly of figures and 
descriptions of the objects of natural history collected during an expedition into the interior of South Africa, in the years 1834, 1835, and 1836; fitted out by "The Cape of Good Hope Association for Exploring Central Africa": together with a summary of African Zoology, and an inquiry into the geographical ranges of species in that quarter of the globe, published under the Authority of the Lords Commissioners of Her Majesty's Treasury, Invertebratae. IV (1849), 53-71.

Milne-Edwards, A., 1862-1865, Monographie des Crustacés fossiles de la famille Cancériens: Annales de Science Naturelle, Zoologie sér. 4, 18 (1862): 31-85; 20 (1863): 273-324; sér. 5, 1 (1864): 31-88; 3 (1865): 297-351.

Monod, T., 1956, Hippidea et Brachyura ouestafricains: Mémoires de l'Institut Français d'Afrique Noire, 45, 674 p.

Ortmann, A., 1892, Die Decapoden-Krebse des Strassburger Museum, mit besonderer Berück- sichtigung der von Herrn Dr. Doederlein bei Japan und bei den LiuKiu-Inseln gesam- melten und zur Zeit im Strassburger Museum aufbewahrten Formen. IV. Die Abtheilun- gen Galatheidea und Paguridea: Zoologische Jahrbüchern, Abtheilung für Systematik, Geographie und Biologie der Thiere, 6, 241-326. https://doi. org/10.5962/bhl.part.26455

Ortmann, A., 1893, Abtheilung: Brachyura (Brachyura genuina Boas), II. Unterabtheilung: Cancroidea, 2. Section: Cancrinea, 1. Gruppe: Cyclometopa. Die Decapoden-Krebse des Strassburger Museums, mit besonderer Berücksichtigung der von Herrn Dr. Döderlein bei Japan und bei den Liu-Kiu-Inseln gesammelten und zur Zeit im Strassburger Museum aufbewahrten Formen, VII Theil: Zoologische Jahrbücher, Abtheilung für Systematik, Geographie und Biologie der Thiere, 7, 411-495.

Ossó, A., Clements, D., 2016, A new genus and species: Pilummede penderensis (Decapoda: Brachyura) from the Castle Hayne Limestone
Formation (Eocene), Pender County, North Carolina (USA): Paleontología Mexicana, 5(2), 137-146.

Rathbun, M.J., 1935, Fossil Crustacea of the Atlantic and Gulf Coastal Plain: Geological Society of America, (special paper) 2, 1-160. https://doi.org/10.1130/spe2-p1

Salva, E.W., Schweitzer-Hopkins, C.E., Feldmann, R.M., 1995, Paleoceanography of decapodrich rocks of the Castle Hayne Formation (Eocene) of North Carolina: Geological Society of America, Abstracts with Program, 27(6), A-368.

Samouelle, G., 1819, The entomologists' useful compendium; or an introduction to the knowledge of British insects, comprising the best means of obtaining and preserving them, and a description of the apparatus generally used; together with the genera of Linné, and modern methods of arranging the Classes Crustacea, Myriapoda, spiders, mites and insects, from their affinities and structure, according to the views of Dr. Leach. Also an explanation of the terms used in entomology; a calendar of the times of appearance and usual situations of near 3000 species of British Insects; with instructions for collecting and fitting up objects for the microscope. London, T. Boys. 496 p. https://doi.org/10.5962/bhl. title.34177

Schweitzer, C.E., 2003, Utility of proxy characters for classification of fossils: an example from the fossil Xanthoidea (Crustacea: Decapoda: Brachyura): Journal of Paleontology, 77, 1107-1128. https://doi.org/10.1666/00223360(2003)0 $77<1107$ : UOPGFG > 2.0. $\mathrm{CO} ; 2$

Schweitzer, C.E., 2005, The genus Xanthilites Bell, 1858 and a new xanthoid family (Crustacea: Decapoda: Brachyura: Xanthoidea): new hypotheses on the origin of the Xanthoidea MacLeay, 1838:Journal of Paleontology, 79(2), 277-295. https://doi.org/10.1666/0022$3360(2005) 079<027$ : TGXBAA>2.0. $\mathrm{CO} ; 2$ 
Schweitzer, C.E., Feldmann, R.M., Garassino, A., Karasawa, H., Schweigert, G., 2010, Systematic list of fossil decapod crustacean species: Crustaceana Monographs, 10, 222 p.

Schweitzer, C.E., Feldmann, R.M., Karasawa, H., 2020, Part R, Revised, Volume 1, Chapter 8T11: Systematic descriptions: Superfamily Majoidea: Treatise Online, 136, 1-31. https://doi.org/10.1163/ ej.9789004178915.i-222

Simms, G., 2012, Geology of the Castle Hayne Limestone in the Onslow Quarry, Richlands, NC: Thesis presented to the Faculty of the Department of Geological Sciences East Carolina University, In Partial Fulfillment of the Requirements for the Degree Master of Science in Geology, $144 \mathrm{p}$.

Stimpson, W.S., 1858, Prodromus descriptionis animalium evertebratorum, quae in
Expeditione ad Oceanum Pacificum Septentrionalem, a Republica Federata missa, Cadwaladaro Ringgold et Johanne Rodgers ducibus, observavit et descripsit. Pars VII. Crustacea Anomura: Proceedings of the Academy of Natural Sciences of Philadelphia, 10, 225-252. https://doi. org/10.5962/bhl.title.51447

Van Straelen, V., 1933, Sur des Crustacés Décapodes Cénozoïque du Venezuela: Bullettin du Museé royal d'Histoire naturelle de Belgique, 9(10), 1-11.

Vía Boada, L., 1959, Decápodos fósiles del Eoceno español: Boletín del Instituto Geológico y Minero de España, 70, 1-72.

Ward, L.W., Lawrence, D.R., Blackwelder, B.W., 1978, Stratigraphic revision of the middle Eocene, Oligocene and lower Miocene Atlantic Coastal Plain of North Carolina: U.S. Geological Survey Bulletin, 1457, 23 p. https://doi.org/10.3133/b1457f 